\title{
Assessment of Aquatic Habitats on the Matador Ranch Phillips Co., MT
}

\author{
Prepared for Linda Poole, The Nature Conservancy
}

by

David M. Stagliano

Aquatic Ecologist

September 2007

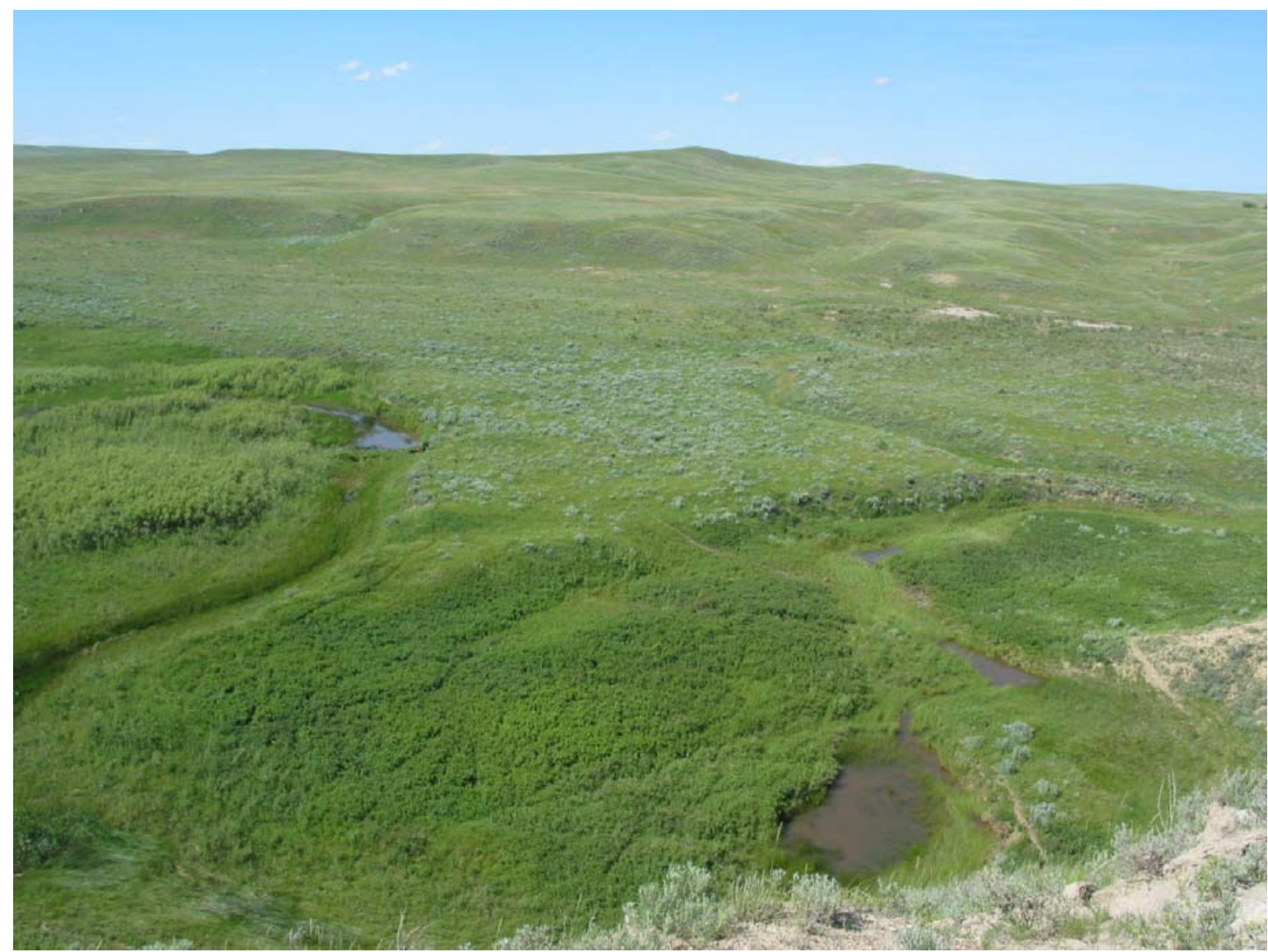

Beaver Creek Landscape from the Buffalo Jump Overlook

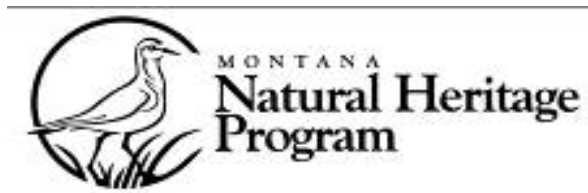

Natural Resource Information System

Montana State Library 


\section{Matador Ranch Aquatics Assessment}

Project goals of the MTNHP Aquatic Surveys of the Matador Ranch were to: 1) survey and analyze macroinvertebrate and/or fish samples collected from a variety of aquatic habitats on the TNC Matador Ranch (Table 1) to assess species distributions and habitat conditions. This report represents local reach-scale, macroinvertebrate assessments that included limited fish surveys from 2005 and 2007.

\section{Sites}

Table 1. Matador Ranch aquatic sites. Sites with an asterisk (*) were also visited in 2005.

\begin{tabular}{lccccc}
\hline Matador Ranch Aquatic Sites & Lat & Long & Date & Time & Elevation \\
\hline & & & & & \\
Little Warm Creek Site \#1* & 47.98961 & -108.314674 & $6 / 21 / 2007$ & $9: 03$ & 2923 \\
Little Warm Creek "cattail pools"* & 47.98535 & -108.322773 & $6 / 21 / 2007$ & $12: 34$ & 2928 \\
Big Warm Creek* & 48.03803 & -108.32982 & $6 / 21 / 2007$ & $10: 35$ & 2880 \\
Matador Perennial Pond & 48.00629 & -108.327329 & $6 / 21 / 2007$ & $11: 49$ & 2949 \\
Fairy Shrimp Ditch Pool & 48.00589 & -108.325053 & $6 / 21 / 2007$ & $12: 10$ & 2941 \\
TNC Corner Spring1 & 47.89846 & -108.202188 & $6 / 21 / 2007$ & $14: 03$ & 2711 \\
TNC Corner Spring2 & 47.89803 & -108.202394 & $6 / 21 / 2007$ & $14: 28$ & 2714 \\
Lone Tree Coulee Pool & 47.93705 & -108.238239 & $6 / 21 / 2007$ & $15: 16$ & 2857 \\
Buffalo Jump Spring & 47.90967 & -108.266813 & $6 / 21 / 2007$ & $16: 21$ & 2860 \\
Beaver Creek Pools & 47.90934 & -108.265728 & $6 / 21 / 2007$ & $16: 40$ & 2855 \\
\hline
\end{tabular}

\section{Methods}

Macroinvertebrate samples, mussel and fish data were collected at 2 Little Warm Creek sites: the county road bridge site in 2005 \& 2007, hereafter, Little Warm Creek Site \#1, and an upper cattail pool area, Little Warm Creek Site \#2, a Big Warm Creek site at the hay field bridge site in 2005 \& 2007. Macroinvertebrate samples only were collected from a roadside ditch (Fairy Shrimp Ditch), a perennial wetland pond, Beaver Creek pools and 4 springs--2 springs called TNC Corner Springs, Buffalo Jump Spring, and a Lone Tree Pool that appeared perennial and spring-fed on June 21, 2007. Macroinvertebrate samples and fish sites from 2005 were sampled 30 July.

\section{Macroinvertebrate Communities}

Macroinvertebrates were collected using the DEQ traveling kick or multi-habitat method (if no riffles are present) with a 500 micron mesh D-frame dip-net (MT DEQ 2005). Samples were preserved in 95\% ETOH and delivered to MTNHP in Helena. Sample processing and bioassessment metrics were performed by David Stagliano at the MTNHP lab in Helena following MT Department of Environmental Quality standardized protocols (MT DEQ 2005). Macroinvertebrates were identified to the lowest taxonomic level, imported into EDAS (Jessup 2006), and biological metrics were calculated from the data using the MT DEQ's multimetric macroinvertebrate (MMI) protocols (Jessup et al. 2005, Feldman 2006). Metric results were then scored using the Montana DEQ bioassessment criteria and each sample categorized as non-impaired or impaired according to threshold values (Table 2). 
Table 2. Impairment determinations from the MMI and O/E (RIVPACS) models (taken from Jessup 2005, Feldman 2006).

\begin{tabular}{l|l|l|l|l|} 
Ecoregion & RlYPACS & MMI & Impaiment Detemination \\
\hline Mountain & $\geq 0.8$ or $\leq 1.2$ & $\geq 63$ & Not impaired \\
Low Valley & $<0.8$ or $>1.2$ & $<63$ & Impaired \\
& $\geq 0.8$ or $\leq 1.2$ & $\geq 48$ & Not impaired \\
& 0.8 or $>1.2$ & $<48$ & Impaired \\
\hline Eastern Flains & $\geq 0.8$ or $\leq 1.2$ & $\geq 37$ & Not impaired \\
& $<0.8$ or $>1.2$ & $<37$ & Impaired \\
\hline
\end{tabular}

\section{Fish Communities.}

Fish sampling in Little Warm Creek sites in 2005 was performed by seining pool areas from the upstream to the downstream direction with a $20 \mathrm{ft} 1 / 4$ inch straight seine (see Pictures of Brian Martin and I). In 2005, Big Warm Creek was sampled by securing the seine in the substrate and "kicking" fish downstream into the seine to be then lifted up at both ends. In 2007, I used a Smith Root Battery Operated Electroshocker for fish collections, proceeding in an upstream direction and netting fish along the way. Fish were transferred to holding buckets, identified to species, enumerated in the field, examined for external anomalies (e.g. deformities, eroded fins, lesions, and tumors), and then released. Vouchers of the northern redbelly dace from the Little Warm Creek Site were submitted to the Montana State University fish collection in 2005. Analysis of the sampled fish communities used derived Observed/Expected (O/E) Fish Models (Stagliano 2005) to detect impairment at the sites by measuring biological integrity of expected fish species for that stream type. We did not propose threshold criteria for good, fair, and poor biological integrity for these fish scores. Therefore, we applied commonly used criteria. Scores of 75 to 100 indicate good to excellent biological integrity, 50-74 fair to good biological integrity, 25 to 49 indicated poor to fair biological integrity and scores $<25 \%$ indicate poor biological integrity or severely impaired.

Mussels. Freshwater mussels were observed with a glass-bottomed bucket searching in an upstream direction prior to the fish and macroinvertebrate surveys and recorded in 2005 and 2007.

Dragonflies and Damselflies. Incidental dragonfly and damselfly observations were made and recorded during the fish and macroinvertebrate surveys in 2005 and 2007.

Amphibian and Reptile Incidentals. Incidental herpetofauna observations were made and recorded in conjunction with the fish and macroinvertebrate surveys. 


\section{Results \\ Three Lotic \& 2 Lentic Aquatic Ecological Systems were classified on the Matador Ranch:}

Lotic AES (Stagliano 2005)

Northern Glaciated Perennial Prairie Stream (AES C006)-1) Big Warm \& Little Warm Creek Northern Glaciated Intermittent Prairie Stream-(AES D006)- 1) Beaver Creek Northwestern Great Plains Perennial Spring/Seep (AES S005)-1) TNC Corner Springs, 2) Buffalo Jump Spring, 3) Lone Tree Pool Spring

\section{Lentic AES}

Northern Glaciated Perennial Prairie Pothole/Pond-(AES code L006)- 1) Matador Ranch Perennial Pond

Northern Glaciated Intermittent Prairie Pools-(AES code E006)- 1) Fairy Shrimp Ditch

Macroinvertebrate Communities: Overall, 80 macroinvertebrate taxa were reported so far from the analyzed samples from the Matador Ranch sites (4 sites have not been evaluated or identified yet) (Appendix A). Four distinct aquatic invertebrate species groups (SPA's) exist on the ranch: the Riverine SPA, the Lentic (Wetland/Pond) SPA, the Perennial Spring SPA, and the Intermittent Prairie Pool SPA. Some sites have combinations of multiple SPA groups. For example Big Warm Creek has unique riverine invertebrate taxa (Ophiogomphus severus, Calopteryx aequabilis, Baetis mayflies, etc.) that are not found in Little Warm Creek, but both sites share most of their other taxa ( 20 shared species). The Intermittent Prairie Pool Sites and Perennial Prairie Pond sites share the majority of taxa except longer-lived taxa (Stagnicola snails, Anax and Aeschna dragronflies) that cannot survive extended dry periods.

Average macroinvertebrate taxa richness per site was 25 and the highest taxa richness reported at the Little Warm bridge site with 36 taxa (Appendix A). Using the Montana DEQ macroinvertebrate multimetric index (MMI), Little Warm and Big Warm Creek bridge sites were ranked non-impaired (good to excellent biological integrity), the Little Warm cattail site \#2 was slightly impaired. Two sites that would rank impaired (data is not complete yet) with the MMI are TNC Corner Springs and Buffalo Jump Springs because they contain anoxic sediments and contain no macroinvertebrates except tolerant Chironomidae and Oligochaeta. The Lone Tree Coulee Intermittent Pool may score fair to good with the O/E as an Intermittent Prairie Pool, but not with the MMI. The best quality site in terms of expected macroinvertebrate community is the Big Warm Creek site because of that sites ability to contain species that exist on clean gravels and cobbles with perennial flows. Little Warm Creek contains some flow but is dominated by the more tolerant species of that assemblage and does not contain the more intolerant riverine species. 


\section{Fish Communities.}

Overall, 6 native fish species were collected on the Matador stream sites (pond sites were not sampled for fish, and the springs were fishless) (Table 3). Little Warm Creek site \#1 picked up an additional species in 2007 compared to 2005. I collected 5 spp. in Big Warm Creek in 2005, but 6 species were collected this past visit in 2007 (Table 3). Brook stickleback and Northern Redbelly dace were collected at all 3 sites both years, while fathead minnows and white suckers occurred at $83 \%$ of the site visits (Table 3). Longnose dace and mottled sculpin were only collected at the Big Warm Creek site (Table 3); this is largely because of the presence of clean gravels (these species are benthic invertivores and lithophilous spawners).

Table 3. Fish species collected at the Matador stream study sites in $2005 \& 2007$. F of O = Frequency of Occurrence of that species across all sites. O/E= Observed/Expected Fish Species.

\begin{tabular}{|c|c|c|c|c|c|c|c|c|}
\hline & 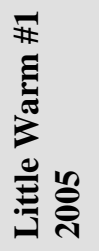 & 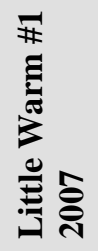 & 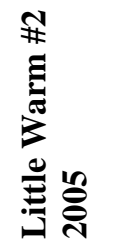 & 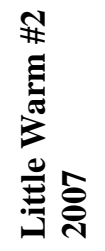 & 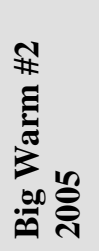 & 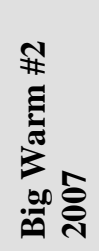 & 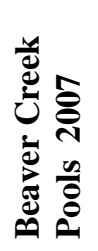 & $F$ of $O$ \\
\hline Brook Stickleback & 7 & 12 & 100 & 2 & 5 & 22 & $\mathbf{0}$ & 1.00 \\
\hline Fathead Minnow & $\mathbf{0}$ & 3 & 75 & 18 & 1 & 1 & $\mathbf{0}$ & 0.83 \\
\hline Longnose Dace & $\mathbf{0}$ & $\mathbf{0}$ & $\mathbf{0}$ & $\mathbf{0}$ & 9 & 65 & $\mathbf{0}$ & 0.33 \\
\hline Mottled Sculpin & $\mathbf{0}$ & $\mathbf{0}$ & $\mathbf{0}$ & $\mathbf{0}$ & $\mathbf{0}$ & 3 & $\mathbf{0}$ & 0.17 \\
\hline Northern Redbelly Dace & 15 & 33 & 100's & 45 & 5 & 14 & $\mathbf{0}$ & 1.00 \\
\hline White Sucker & 1 & 2 & $\mathbf{0}$ & 2 & 6 & 8 & $\mathbf{0}$ & 0.83 \\
\hline Total Individuals & 23 & 50 & $\sim 500$ & 65 & 26 & 113 & $\mathbf{0}$ & \\
\hline Total \# species & 3 & 4 & 3 & 4 & 5 & 6 & $\mathbf{0}$ & \\
\hline Native Species & 3 & 4 & 3 & 4 & 5 & 6 & $\mathbf{0}$ & \\
\hline O/E & 0.75 & 1.0 & 0.75 & 1.0 & 1.0 & 1.0 & 0 & \\
\hline
\end{tabular}

Using the $\mathrm{O} / \mathrm{E}$ scoring system, 3 of the 4 fish sites ranked non-impaired for both years ( $>0.75=$ good to excellent biological integrity), and 1 site ranked impaired (the Beaver Creek pools) (Table 3) because at least 1 fish species could have been expected for this stream type, but was not collected. The Mottled Sculpin (Cottus bairdi) population in Big Warm Creek is a unique find this far into eastern MT, and is an indicator of the cooler spring-fed nature of this stream; sculpin are typically cool-water system inhabitants. 
Dragonflies and Damselflies. Five dragonfly species were common across most lotic/lentic sites (Common Green Darner, Anax junius; Variable Darner, Aeshna interrupta, the 12-spotted skimmer, Libelulla pulchella; Eight-spotted Skimmer Libellula forensis (Photo left) and the Variagated Meadowhawk, Sympetrium corruptum.
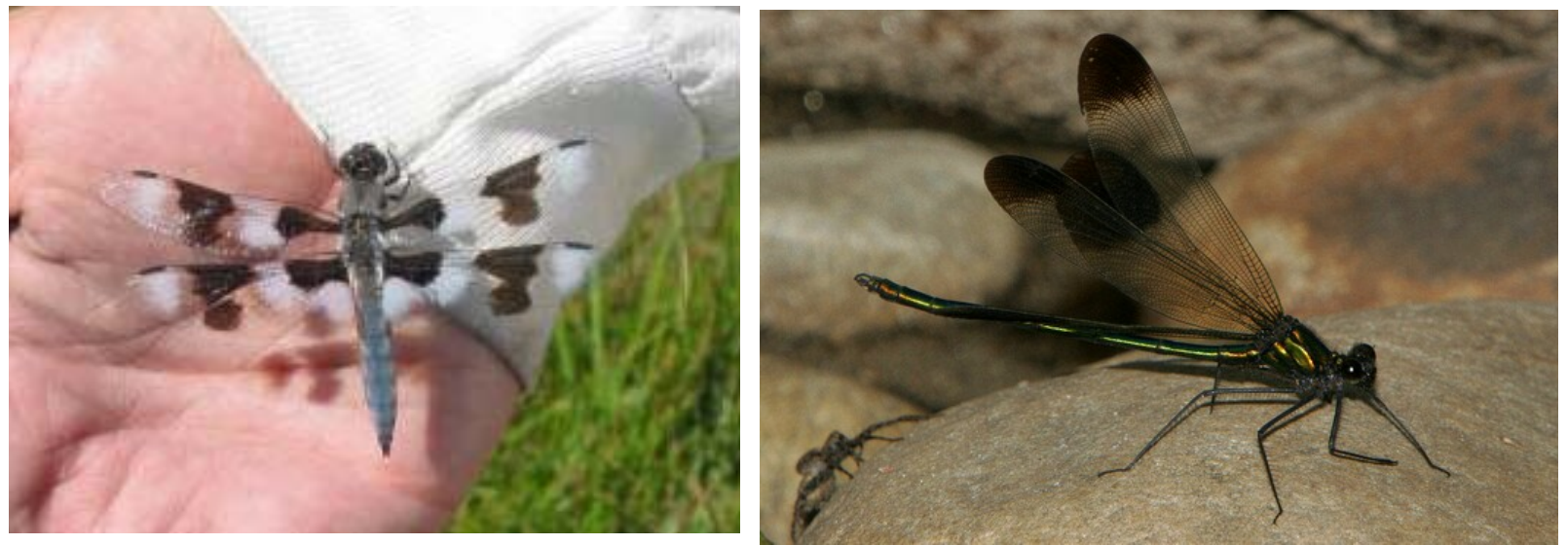

No species of concern (SOC) were noted at any sites.

The pale snaketail dragonfly, Ophiogomphus severus, and the river jewelwing damselfly, Calopteryx aequabilis (a Potential SOC, Photo right above) were only recorded at the Big Warm Creek site. The damselflies (Familiar Bluet, Enallagma civile, Northern Bluet, Enallagma cyathigerum; Eastern Forktail, Ischnura verticalis and the Common Spreadwing, Lestes disjunctus) were common at most stream pools or lentic sites.

\section{Amphibian and Reptile Incidentals}

Five amphibian species (Woodhouse's Toad, Bufo woodhousei; Great Plains Toad, Bufo cognatus; Plains Spadefoot, Spea bombifrons; Tiger salamander, Ambystoma tigrinum and the Northern Leopard Frog, Rana pipiens) and 2 reptile species (Painted Turtles, Chysemys picta \& the Plains Garter Snake, Thamnophis radix) were recorded during all surveys. 


\section{Site Descriptions: Northern Glaciated Perennial Prairie Stream (AES C006)}

Management/Threats to this ecological system include:

Grazing and livestock use around the riparian areas that is occurring or has occurred in the past can have strong local effects resulting in sedimentation and stream widening at cattle crossings. Introductions of game or forage fish in stock ponds anywhere in the watershed can make their way downstream to these perennial prairie rivers and become permanent residents, competing with (green sunfish) or preying upon (northern pike) resident native fish species

These prairie river ecological types are abundant in terms of river miles across the Northern Great Plains Steppe of North America, but the hydrology (i.e. water permanence) can be easily affected by upstream dams or diversions in the watershed. Stock ponds that are stocked with game fish, and bait bucket introductions can also contribute to the community degradation brought about by the introduced fish species.

\section{Little Warm Creek (Bridge Site \#1)}

Location: Accessed from Bridge Crossing first run/pool set designated the top of the reach.

Ecoregion: Northern Glaciated Plains (Typical)

Aquatic Ecological System Type: C006-Northern Glaciated Perennial Prairie Stream

Key Environmental Factors: Hydrology--upstream dams or diversions in the watershed; depositional silted areas forming cattail (Typha latifolia) mats, Grazing--slight impacts.

Rare or Unique Species: No rare species, but native fish community

Rare Features: Good Prairie Stream Habitat

Introduced/Exotic Aquatic Species: None

Overall Ecological Site Condition: Fair trending to Good

This stream reach has a fair diversity of microhabitats including undercut banks and aquatic vegetation leading to a fair fish community (4 native species). Pools averaged $30 \mathrm{~m}$ long and $2.9 \mathrm{~m}$ wide. The pool complexes proceeding upstream were deep enough to allow seining for fish. All substrate of the pools was dominated by silt/organic materials with some pebbles and gravels.

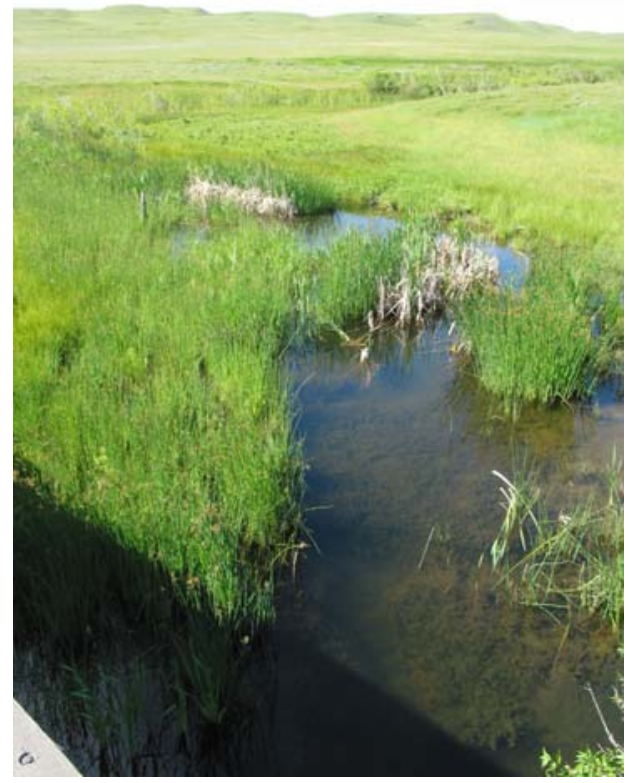

Macroinvertebrate Community: This community of prairie stream invertebrates consists of the Prairie Pool assemblage (\#12, Stagliano 2005). The community indicator species are characterized by tolerant, damselfly taxa, Coenagrion /Enallagma sp., Lestes and Ishnura, the crustaceans (Hyalella and Gammarus), many genera of the water boatman (Corixidae: Sigara alternate, Trichocorixa nais, and Corisella), the snails (Physella, Gyraulus, and Stagnicola), mayflies (Caenis and Callibaetis), and beetles (Oreodytes, Laccophilus, Hydroporus and Hygrotus).

Only $70 \%$ of the indicator species were present in this sample, but the DEQ MMI is showing good to excellent biointegrity.

Macroinvertebrate Community Quality:

MTDEQ MMI $=47.1 \quad \mathrm{O} / \mathrm{E}=\mathbf{7 0} \%$ 


\section{Little Warm Creek (Cattail Pools site \#2)}

Location: Accessed from left turn on county road upstream $\sim 500 \mathrm{~m}$ from the Bridge Crossing. Ecoregion: Northern Glaciated Plains (Typical)

Aquatic Ecological System Type: C006-Northern Glaciated Perennial Prairie Stream

Key Environmental Factors: Hydrology--upstream dams or diversions in the watershed; depositional silted areas forming large cattail mats (Typha latifolia), Grazing-no noticeable impacts.

Rare or Unique Species: No rare species, but native fish community

Rare Features: Good Riparian Prairie Stream Habitat with a dense snowberry and willow zone ithin this reach.

Introduced/Exotic Aquatic Species: None

Overall Ecological Site Condition: Fair

Macroinvertebrate Community: This community of prairie stream invertebrates consists of the Prairie Pool assemblage (\#12, Stagliano 2005). The community indicator species are characterized by tolerant, damselfly taxa, Coenagrion /Enallagma sp., Lestes and Ishnura, the crustaceans (Hyalella and Gammarus), many genera of the water boatman (Corixidae: Sigara alternate, Trichocorixa nais, and Corisella), the snails (Physella, Gyraulus, and Stagnicola), mayflies (Caenis and Callibaetis), and beetles (Oreodytes, Laccophilus, Hydroporus and Hygrotus).

Only $60 \%$ of the indicator species were present in this sample, and the DEQ MMI is indicating a slightly impaired biological integrity.

Macroinvertebrate Community Quality:

MTDEQ MMI $=35.2 \quad 0 / E=60 \%$
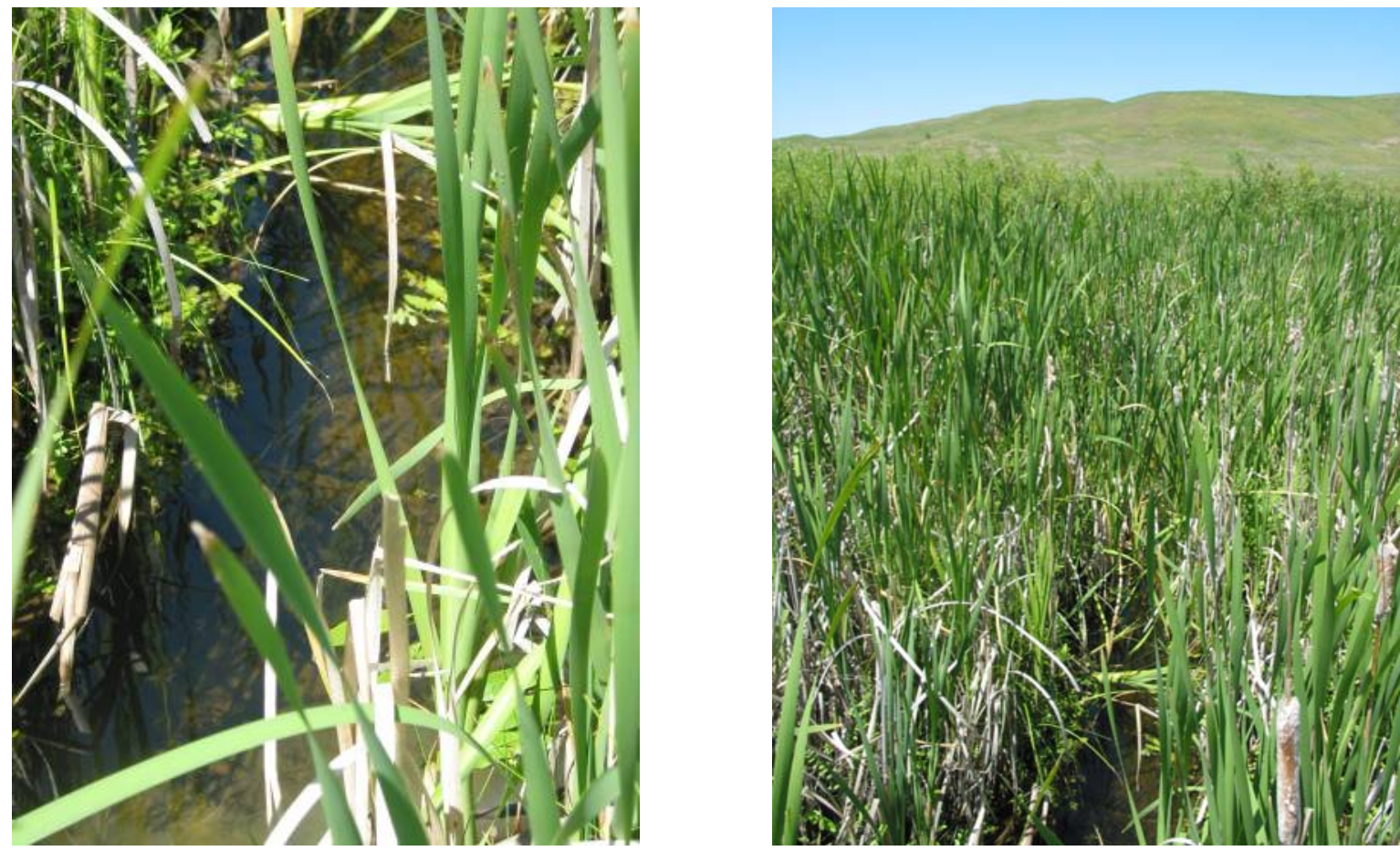


\section{Big Warm Creek (Bridge Site \#1)}

Location: Accessed from 2-track past the Ranch House to the Hay Meadows.

Ecoregion: Northern Glaciated Plains (Typical 42).

Aquatic Ecological System Type: C006-Northern Glaciated Perennial Prairie Stream

Key Environmental Factors: Hydrology--upstream dams or diversions in the watershed; depositional silted areas forming large Scirpus mats (Big Stem Bulrush), Grazing-no noticeable impacts.

Rare or Unique Species: No SOC species, but native fish community + the freshwater mussel

(Pyganodon grandis) and the PSOC river jewelwing damselfly (Calopteryx aequabilis).

Rare Features: none.

Introduced/Exotic Aquatic Species: None

Overall Ecological Site Condition: Fair trending to Good

This stream reach has a fair diversity of microhabitats including undercut banks, gravel runs, cobbles and aquatic vegetation, leading to a good fish community ( 6 native species). The reach is dominated by a long run with some side-depositional pools, it averaged $2.1 \mathrm{~m}$ wide with channel depths of $\sim 30 \mathrm{~cm}$.

\section{Macroinvertebrate Community Quality: MTDEQ MMI= 54.5 O/E= 80\%}

The freshwater mussel, giant floater (Pyganodon grandis) population is doing very well ( 75 individuals in the $50 \mathrm{~m}$ reach surveyed) most of these are $3-5$ year olds $(40-50 \mathrm{~mm}$, right in photo), but there is evidence of recent recruitment, $1-2 \mathrm{yrs}(20-30 \mathrm{~mm}$, left in photo). They are located in the gravel/silt interface where streamflow keeps the substrate clean. Host fish=brook stickleback
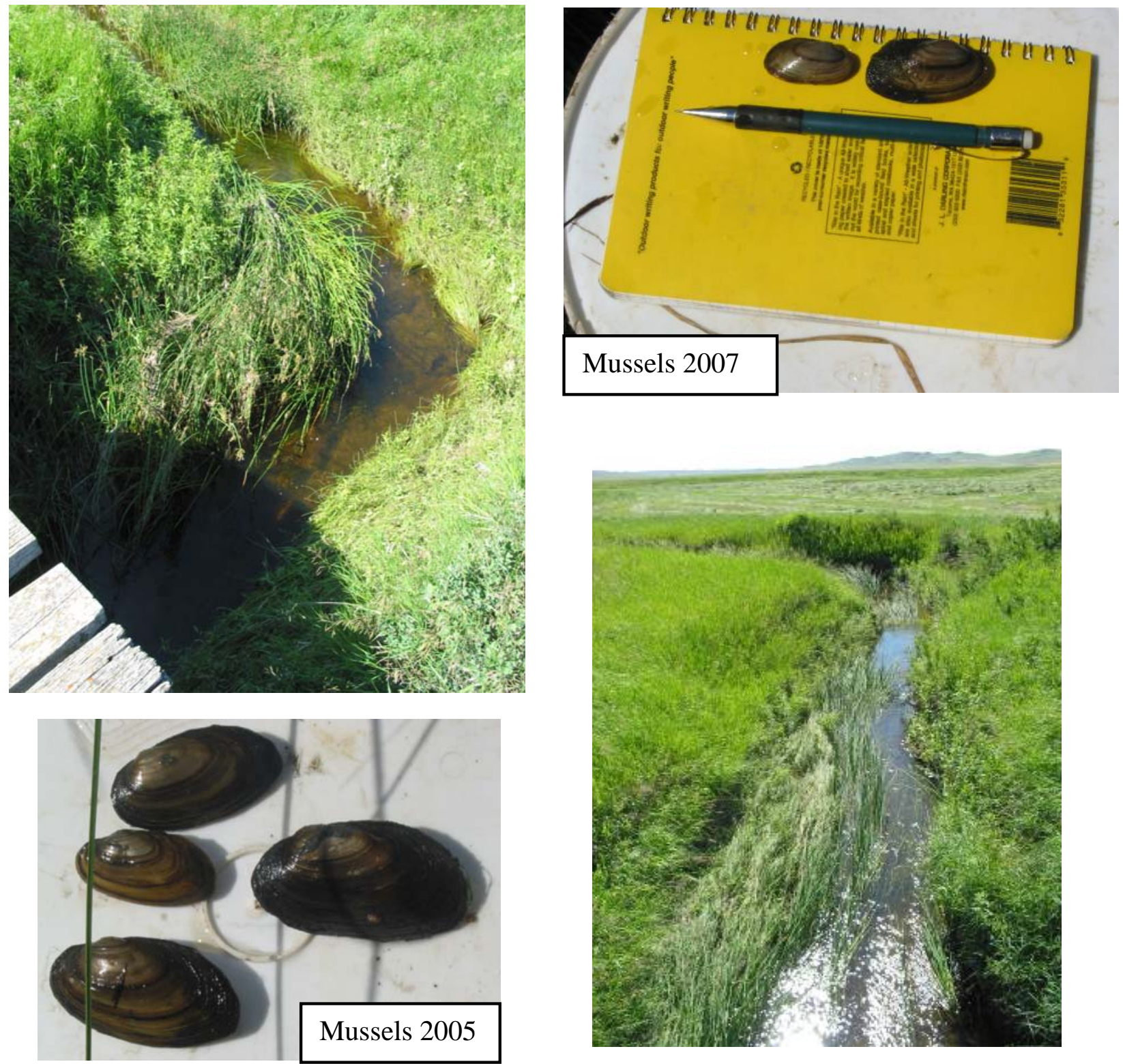


\section{Matador Perennial Pond}

Scirpus (Big Stem Bulrush) emergent vegetation dominated, with Spikerush (Elocharis sp.) present and abundant. Fully aquatic plants included Meriophyllum sp. and Potamogeton sp.

Macroinvertebrate Community: This community of prairie stream invertebrates consists of the Prairie Pool assemblage (SPA \#12, Stagliano 2005). The 2007 sample was dominated by the snails (Physella100's), (Gyraulus, Helisoma anceps and Stagnicola -a few), the damselfly taxa, Coenagrion /Enallagma sp, Lestes spp.\& Ishnura, the crustaceans (Hyalella and Gammarus), many genera of the water boatman (Corixidae), the backswimmers, Notonecta, the mayfly (Callibaetis), and water-beetles (Oreodytes, Laccophilus, Hydroporus and Hygrotus).

Painted turtles and woodhouse's toad (Bufo woodhousei) tadpoles were abundant .
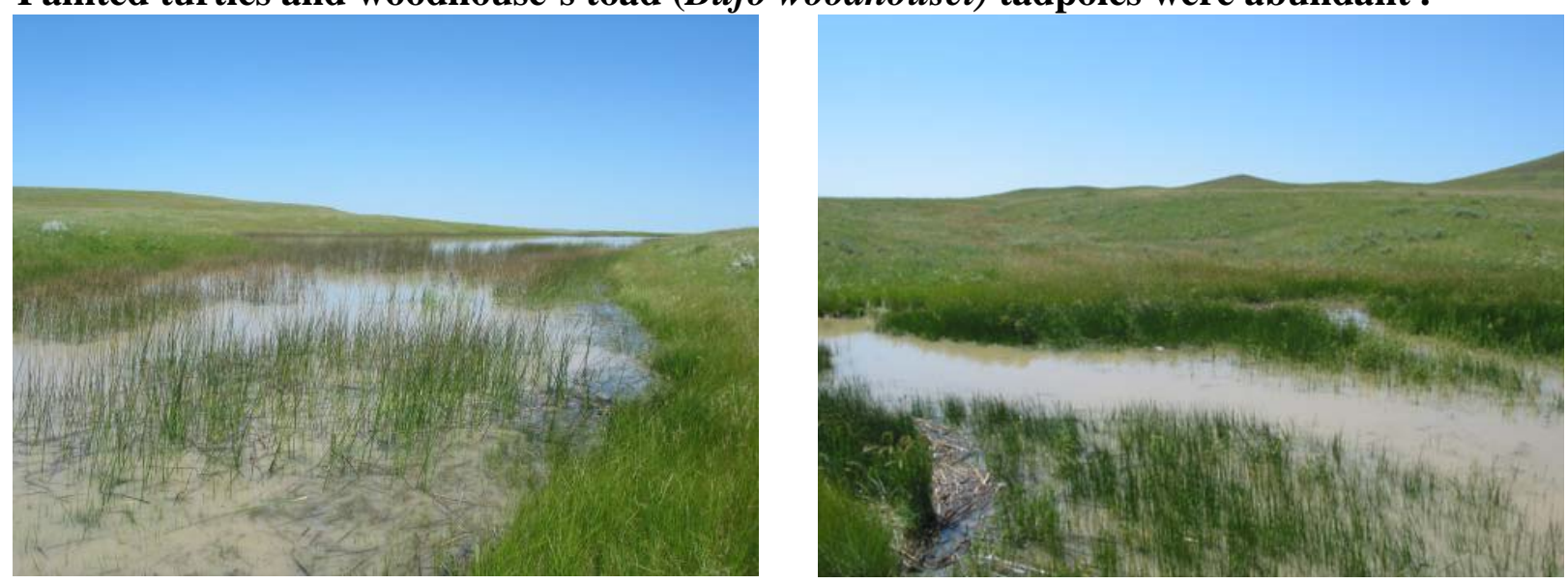

\section{Fairy Shrimp Pools near Matador Perennial Pond:}

This roadside ditch pool was sampled on the way to the perennial pond across the road when I noticed movement within the recently ( 2 weeks) filled old stream channel. Upon investigation and a few dipnet sweeps, the common fairy shrimp: Branchinecta paludosa (see picture) was found to be highly
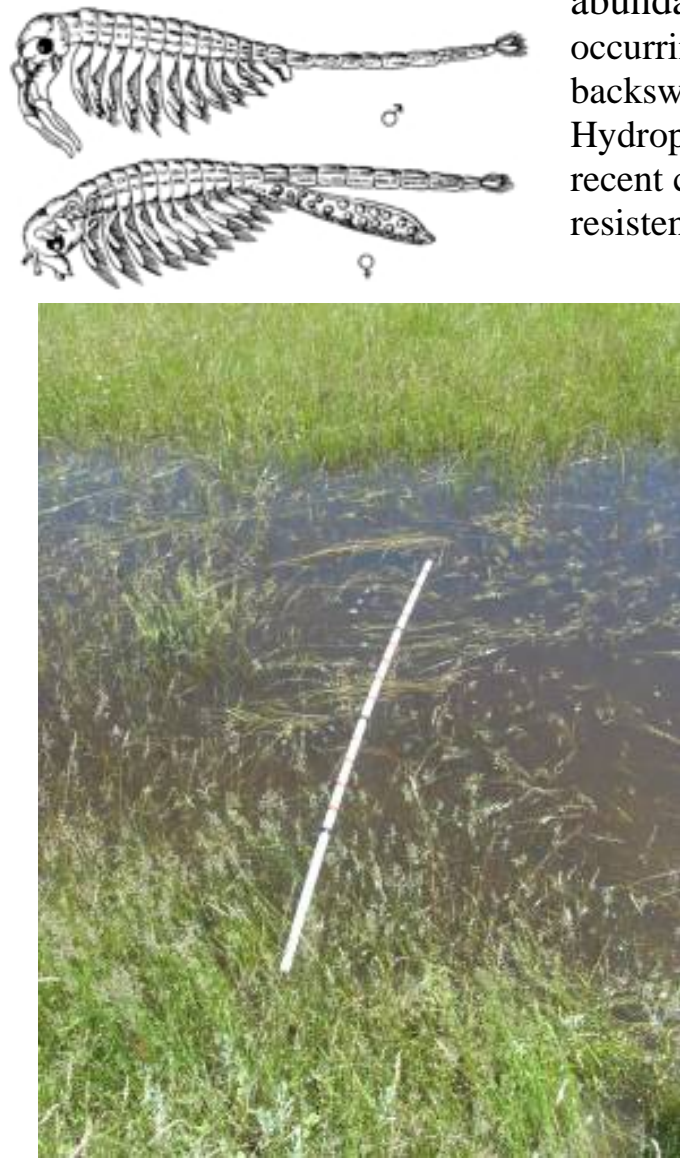
abundant (hundreds per sq. meter) in these isolated pools. Cooccurring with the fairy shrimp were Ostracoda crustaceans, backswimmer waterbugs: Notonecta, and the pioneering Hydrophilidae beetles: Hydrobious and Berosus. These insects were recent colonizers, while the crustaceans were hatched from droughtresistent diapausing eggs that were lying dormant in the substrate. 


\section{Buffalo Jump Spring:}

The initial outflow is coming out of a $2 \times 4$ meter seepage area at a temperature of $13^{\circ} \mathrm{C} / 56$ ${ }^{\circ} \mathrm{F}$, the sediments are anoxic ( $0 \mathrm{mg} / \mathrm{l}$ of oxygen at the sediment surface), thus most of the invertebrates are clinging to the vegetation, only Oligochaeta worms were found in the sediments. Emergent wetland vegetation is dominated by a Spikerush (Eleocharis sp.)

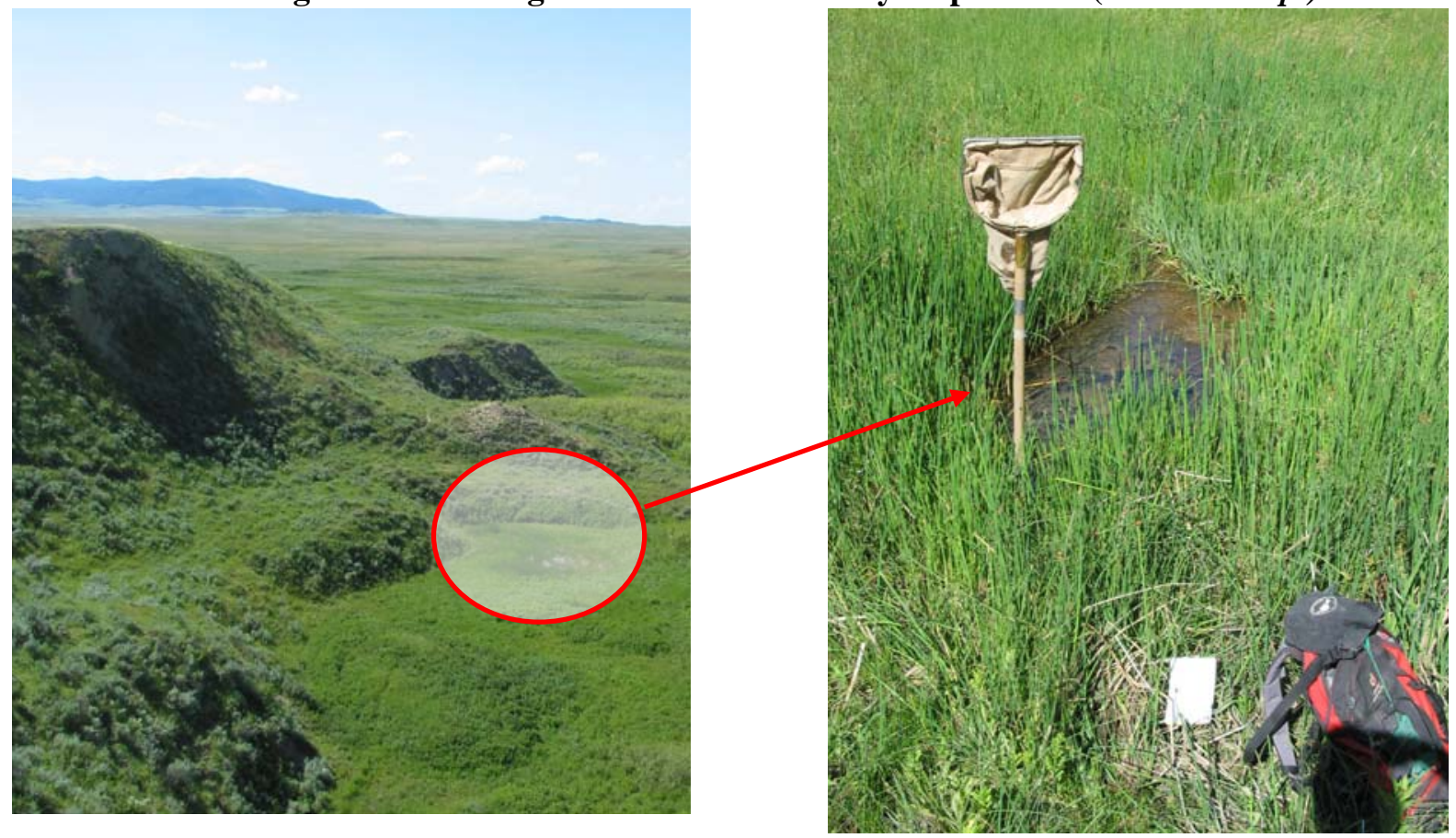

\section{TNC Corner Section Springs}

The initial outflow is coming out of $2-8 \times 8$ meter seepage areas, densely surrounded by Scirpus sp (Big Stem Bulrush)(Left photo) and cattails (Typha latifolia)(right photo) at a temperature of $14^{\circ} \mathrm{C} / 58^{\circ} \mathrm{F}$, the sediments are silted and anoxic $(0 \mathrm{mg} / \mathrm{l}$ of oxygen at the sediment surface), thus most of the invertebrates are clinging to the vegetation, only Oligochaeta worms were found in the sediments. A side channel has water temperatures of $28^{\circ} \mathrm{C} / 8^{\circ} \mathrm{F}$ indicating a surface flow origin. Plains spadefoot toad tadpoles collected in the pools below springs.
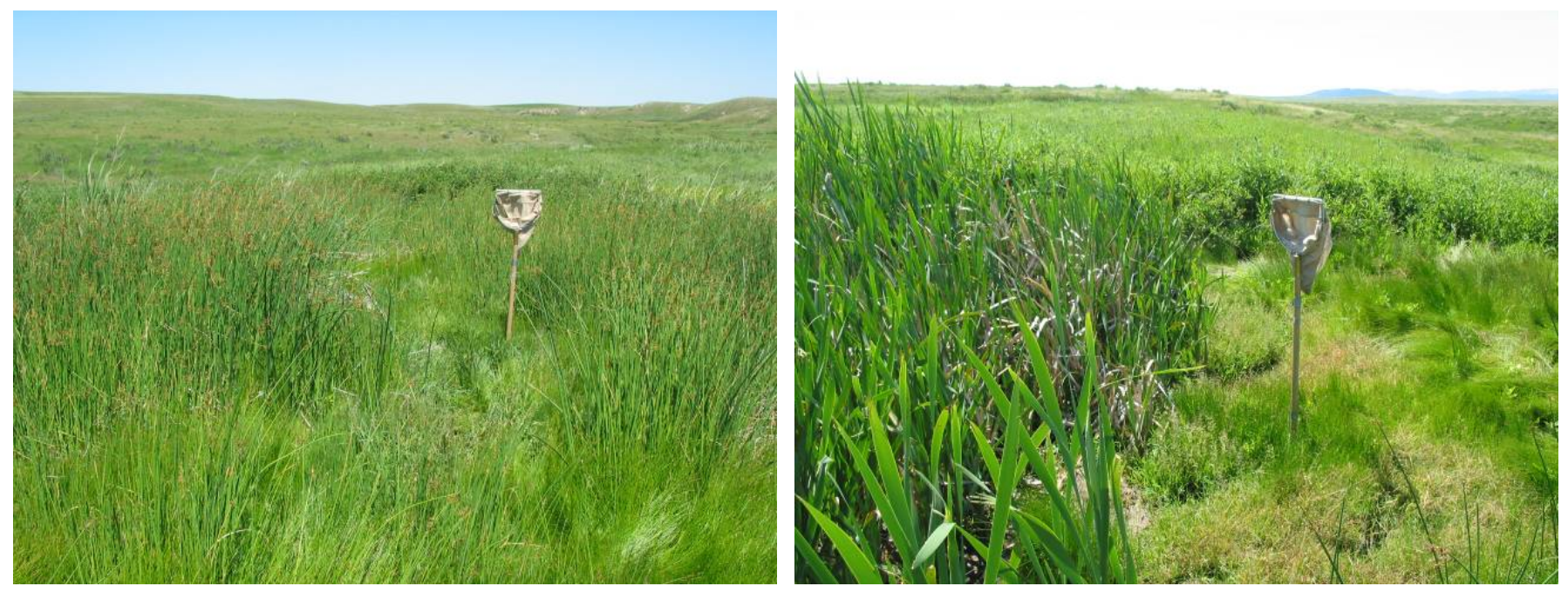


\section{Lone Tree Pool on the Coulee (Spring?)}

The outflow was not located but was assumed to be feeding this perennial pool from subsurface. This pool ( $40 \mathrm{~m}$ long $\mathrm{x} 4 \mathrm{~m}$ wide) is densely surrounded by Scirpus sp (Big Stem Bulrush) and remnants of dying cattails (Typha latifolia). The surface temperature of the pool was $23^{\circ} \mathrm{C} / 73^{\circ} \mathrm{F}$, the sediments are silt and anoxic organic materials $(0 \mathrm{mg} / \mathrm{l}$ of oxygen at the sediment surface), thus most of the invertebrates are clinging to the vegetation; only Oligochaeta worms and midges (chironomidae) were found in the sediments.

Macroinvertebrate Community: This community of prairie stream invertebrates consists of the Prairie Pool assemblage (\#12, Stagliano 2005). The community indicator species are characterized by tolerant, damselfly taxa, Coenagrion /Enallagma sp., Lestes and Ishnura, the crustaceans (Hyalella and Gammarus), many genera of the water boatman (Corixidae: Sigara alternate, Trichocorixa nais, and Corisella), the snails (Physella, Gyraulus, and Stagnicola), the mayfly , Callibaetis, and beetles (Oreodytes, Laccophilus, Hydroporus and Hygrotus).

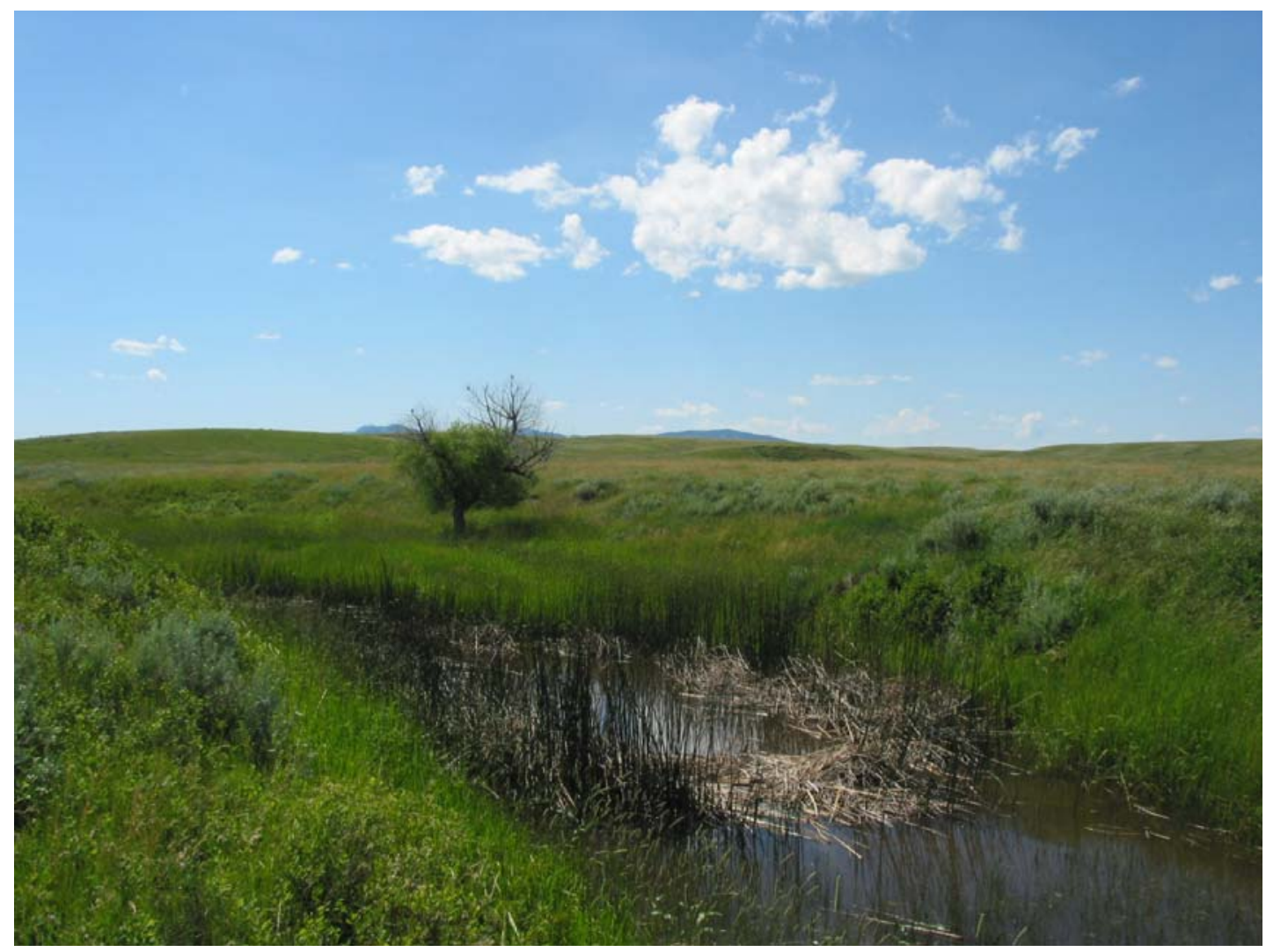

\section{Beaver Creek Pools \#1 (see cover photo).}

These intermittent pools were $23.5^{\circ} \mathrm{C} / 74^{\circ} \mathrm{F}$ and have been recently inundated by thunderstorms and surface run-off flow, therefore the macroinvertebrates existing there are recent fly-in colonizers, and included the pioneering Hydrophilidae water beetles: Hydrobious and Berosus and backswimmer waterbugs: Notonecta, and waterboatmen, Corixidae. 


\section{Appendix A:}

\section{Montana Bioassessment Report}

Waterbody Name: Little Warm Creek \#1

Benthic Sample ID: 14933

Station ID: MOTNCSQ101

Rep. Num: 0

Reference

STORET Activity ID: $\quad$ TNC1Q5-M

Site Classification:

Collection Date: $\quad$ 07/30/2005

Latitude:

Collection

MTkick500

Longitude:

Total Number of Individuals in Sample:

\section{Sample Taxa List}

\begin{tabular}{|c|c|c|c|c|c|c|}
\hline Order: & OTU name: & FinalID: & Individuals & Tol Val: & FFG: & Habit: \\
\hline Hirudina & & Glossiphona complanata & 2 & & & \\
\hline Amphipoda & Gammarus & Gammarus & 2 & 4 & CG & "SW/50\%, SP/50\%" \\
\hline Amphipoda & Hyalella & Hyalella & 69 & 8 & CG & SW/SP \\
\hline Basommatop & Physa_Physella & Physella & 13 & 8 & CG & $\mathrm{CN}$ \\
\hline BASOMMAT & Planorbidae & HELISOMA ANCEPS & 12 & 7 & $\mathrm{SC}$ & \\
\hline Basommatop & Planorbidae & Planorbella & 8 & & $\mathrm{SC}$ & $\mathrm{CN}$ \\
\hline COLEOPTE & & DINEUTUS & 3 & 4 & PR & \\
\hline Coleoptera & Dubiraphia & Dubiraphia & 2 & 6 & SC/CG & "CN/50\%, BU/50\%" \\
\hline Coleoptera & Tropisternus & Tropisternus & 2 & & PR & "CN,SP,CM(la), \\
\hline Diptera & Chironominae & Cryptochironomus & 2 & 8 & PR & $\mathrm{BU} / \mathrm{SP}$ \\
\hline Diptera & Chironominae & Dicrotendipes & 1 & 8 & CG & BU \\
\hline Diptera & Chironominae & Paratanytarsus & 18 & 6 & CG & SP \\
\hline Diptera & Chironominae & Polypedilum & 2 & 6 & $\mathrm{SH}$ & $\mathrm{CN}$ \\
\hline Diptera & Chironominae & Pseudochironomus & 3 & 5 & CG & $\mathrm{BU}$ \\
\hline Diptera & Chironominae & Tanytarsus & 21 & 6 & $\mathrm{CF}$ & $\mathrm{CN}$ \\
\hline Diptera & Dixella & Dixella & 2 & & CG & SW \\
\hline Diptera & Orthocladiinae & Heterotrissocladius & 2 & 0 & CG/SC & SP/BU \\
\hline Diptera & Orthocladiinae & Psectrocladius & 1 & 8 & CG & BU \\
\hline Diptera & Tanypodinae & Procladius & 4 & 9 & PR & SP \\
\hline Diptera & Tanypodinae & Thienemannimyia Gr. & 3 & 5 & PR & $\mathrm{SP}$ \\
\hline Ephemeropte & & Caenis amica & 1 & 7 & CG & "SP/75\%, CM/90\%" \\
\hline Ephemeropte & Caenis & Caenis latipennis & 5 & 7 & CG & "SP/75\%, CM/90\%" \\
\hline Hemiptera & Corixidae & Corixidae & 4 & 9 & $\mathrm{PH} / \mathrm{PR}$ & SW \\
\hline Odonata & & Aeshna eremita & 2 & 7 & PR & unk \\
\hline Odonata & Anax & Anax junius & 2 & 6 & PR & unk \\
\hline Odonata & Coenagrionidae & Coenagrion/Enallagma & 9 & 7 & PR & unk \\
\hline Odonata & Libellulidae & Sympetrum & 1 & 9 & PR & unk \\
\hline Veneroida & Pisidiidae & Pisidium & 15 & 8 & $\mathrm{CF}$ & $\mathrm{BU}$ \\
\hline Veneroida & Pisidiidae & Sphaerium & 2 & 8 & $\mathrm{CF}$ & $\mathrm{BU}$ \\
\hline
\end{tabular}

Metric:

EPT Taxa:

Tanypodinae Percent:

Orthocladiinae/Midges:

Predator Taxa:

Collector + Filterer Pct:
Value Score

$1.0 \quad 7.1$

$3.3 \quad 32.9$

$5.3 \quad 94.7$

$7.0 \quad 77.8$

$84.5 \quad 23.8$




\section{Appendix A: cont.}

\section{Montana Bioassessment Report}

Waterbody Name: Little Warm Creek \#2

Benthic Sample ID: 14934

Station ID: MOTNCSQ102

Reference

Site Classification:

Latitude:

Longitude:

\section{Sample Taxa List}

$\begin{array}{ll}\text { Order: } & \text { OTU name: } \\ \text { Hirudina } & \\ \text { Amphipoda } & \text { Gammarus } \\ \text { Amphipoda } & \text { Hyalella } \\ \text { Basommatop } & \text { Physa_Physella } \\ \text { BASOMMAT } & \text { Planorbidae } \\ \text { Coleoptera } & \text { Haliplus } \\ \text { Coleoptera } & \text { Dubiraphia } \\ \text { Coleoptera } & \text { Tropisternus } \\ \text { Diptera } & \text { Chironominae } \\ \text { Diptera } & \text { Chironominae } \\ \text { Diptera } & \text { Chironominae } \\ \text { Diptera } & \text { Chironominae } \\ \text { Diptera } & \text { Chironominae } \\ \text { Diptera } & \text { Chironominae } \\ \text { Diptera } & \text { Tanypodinae } \\ \text { Diptera } & \text { Tanypodinae } \\ \text { Ephemeropte } & \text { Caenis } \\ \text { Hemiptera } & \text { Corixidae } \\ \text { Odonata } & \\ \text { Odonata } & \text { Anax } \\ \text { Odonata } & \text { Coenagrionidae } \\ \text { Odonata } & \text { Libellulidae } \\ & \end{array}$

FinalID:

Glossiphona complanata

Gammarus

Hyalella

Physella

HELISOMA ANCEPS

Haliplus

Dubiraphia

Tropisternus

Chironomus

Dicrotendipes

Paratanytarsus

Polypedilum

Pseudochironomus

Tanytarsus

Procladius

Thienemannimyia Gr.

Caenis latipennis

Corixidae

Aeshna eremita

Anax junius

Coenagrion/Enallagma

Sympetrum
Rep. Num: 0

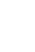

\author{
STORET Activity ID: TNC1Q5-M \\ Collection Date: $\quad$ 07/30/2005 \\ Collection \\ MTkick500 \\ Total Number of Individuals in Sample:
}




\section{Montana Bioassessment Report}

Waterbody Name: Big Warm Creek

Station ID: MOTNCSQ103

Reference

Site Classification:

Latitude:

Longitude:

\section{Sample Taxa List}

$\begin{array}{ll}\text { Order: } & \text { OTU name: } \\ \text { Amphipoda } & \text { Hyalella } \\ \text { Basommatop } & \text { Physa_Physella } \\ \text { Basommatop } & \text { Planorbidae } \\ \text { Coleoptera } & \text { Dubiraphia } \\ \text { Coleoptera } & \text { Optioservus } \\ \text { Diptera } & \text { Chironominae } \\ \text { Diptera } & \text { Chironominae } \\ \text { Diptera } & \text { Chironominae } \\ \text { Diptera } & \text { Chironominae } \\ \text { Diptera } & \text { Dixella } \\ \text { Diptera } & \text { Orthocladiinae } \\ \text { Diptera } & \text { Orthocladiinae } \\ \text { Diptera } & \text { Tanypodinae } \\ \text { Ephemeropte } & \text { Caenis } \\ \text { Ephemeropte } & \text { Baetis } \\ \text { Hemiptera } & \text { Corixidae } \\ \text { Odonata } & \\ \text { Odonata } & \\ \text { Odonata } & \\ \text { Odonata } & \text { Coenagrionidae } \\ \text { Odonata } & \text { Libellulidae } \\ \text { Veneroida } & \text { Pisidiidae } \\ \text { Veneroida } & \text { Pisidiidae } \\ & \end{array}$

FinalID:
Hyalella
Physella
Planorbella
Dubiraphia
Optioservus
Dicrotendipes
Polypedilum
Pseudochironomus
Tanytarsus
Dixella
Heterotrissocladius
Cricotopus
Thienemannimyia Gr.
Caenis latipennis
Baetis tricaudatus
Corixidae
Aeshna eremita
Ophiogomphus severus
Calopteryx aequiabus
Coenagrion/Enallagma
Sympetrum
Pisidium
Sphaerium

Individuals

Metric:

Value Score

Plains MMI

54.5

22
24
8
2
18
1
21
3
21
2
2
5
8
5
22
9
4
6
2
22
2
15
12

Benthic Sample ID: 14935

Rep. Num: 0

STORET Activity ID: $\quad$ TNC1Q5-M

Collection Date: $\quad$ 07/30/2005

Collection

MTkick500

Total Number of Individuals in Sample:

Tol

Habit:

$\begin{array}{cc}\text { CG } & \text { SW/SP } \\ \text { CG } & \text { CN } \\ \text { SC } & \text { CN }\end{array}$

"CN/50\%, BU/50\%"

"CN/50\%, BU/50\%"

$\begin{array}{cr}\mathrm{SC} / \mathrm{CG} & \mathrm{CN} / 50 \%, \\ \mathrm{CG} & \mathrm{BU}\end{array}$

$\mathrm{SH} \quad \mathrm{CN}$

CG BU

CF $\quad \mathrm{CN}$

CG SW

CG/SC SP/BU

PR SP

CG "SP/75\%, CM/90\%"

CG "SP/75\%, CM/90\%"

PH/PR SW

PR unk

PR unk

PR unk

PR unk

PR unk

CF BU
CG BU

$\begin{array}{lcc}\text { EPT Taxa: } & 2.0 & 15.1 \\ \text { Tanypodinae Percent: } & 4.3 & 29.9 \\ \text { Orthocladiinae/Midges: } & 5.3 & 94.7 \\ \text { Predator Taxa: } & 7.0 & 77.8 \\ \text { Collector + Filterer Pct: } & 64.5 & 33.8\end{array}$

